\title{
Pollen morphology of Acalypha L. (Euphorbiaceae) with emphasis on Brazilian species from Bahia
}

\author{
Airã de Lima Bomfim ${ }^{1}$ (D) Francisco de Assis Ribeiro dos Santos ${ }^{1 *}$ (D) and Daniela Santos Carneiro Torres ${ }^{1}$
}

Received: October 7, 2020

Accepted: March 9, 2021

\begin{abstract}
We investigated the pollen morphology of eight species of Acalypha occurring in Bahia State, Brazil. Flower buds were collected from specimens deposited in the CEPEC and HUEFS herbaria. Pollen samples were acetolyzed and analyzed using both light and scanning electron microscopy. The pollen grains examined using optical microscopy were found to be small and brevicolporate, with three to six apertures and elevations and fastigium, and had a psilate to scabrate exine. Scanning electron microscopy revealed the presence of supratectal elements and Ubisch bodies, and evidenced three pollen types based mainly on exine ornamentation: microrugulate-scabrate (slightly rugulate-scabrate), areolate-rugulate, and microechinate. This study provides new data and new interpretations of pollen morphology for the genus Acalypha, with comments on the palynological relationships between Acalypha and its sister group Mareya, and the next most closely related genus (Spathiostemon).
\end{abstract}

Keywords: Acalypheae, Acalyphoideae, fastigium, palynology, palynotaxonomy

\section{Introduction}

The family Euphorbiaceae has cosmopolitan distribution, occurring mainly in tropical areas (Heywood et al. 2007). In Brazil, Euphorbiaceae is represented by 950 species distributed within 64 genera that grow in varied habits and different vegetation types (Flora do Brasil 2020 2018).

According to Cardiel et al. (2015), the genus Acalypha is the third-largest genus of Euphorbiaceae, comprising approximately 500 species with pantropical distributions and with high degrees of endemism in the Americas; few of its species reach temperate regions. One of the most complete and accepted taxonomic treatments of Acalypha is that of Pax \& Hoffman (1924), which considered 390 species.
Species segregations mainly consider the inflorescence, indumentum, stipules, and leaf venation (Seberg 1984).

The monophyletism of the genus and the classification of its subgenera (A. subg. Acalypha, A. subg. Androcephala and A. subg. Linostachys (Sagun et al. 2006; Cardiel et al. 2018)) are currently supported by molecular data. According to Wurdack et al. (2005), the sister group of Acalypha is the genus Mareya, with the next most closely related genus being Spathiostemon.

Acalypha can be easily identified by its unisexual flowers (which lack parts), discs, staminodes, and pistillodes. The staminate flowers bear distinctively pendular and vermiform anthers that produce small, brevicolpate pollen grains (Sagun et al. 2006); the pistillate flowers usually have laciniate styles, with anther and style morphologies being synapomorphies for the genus (Webster 1994).

1 Programa de Pós-Graduação em Botânica, Universidade Estadual de Feira de Santana, 44036-900, Feira de Santana, BA, Brazil

* Corresponding author: f.a.r.santos@gmail.com 
Acalypha is represented in Brazil by approximately 50 species (Flora do Brasil 2020 2018) distributed into two subgenera: A. subg. Acalypha and A. subg. Linostachys. The following taxa were found in Bahia State, based on surveys carried out in herbaria and reviews of the specialized literature: Acalypha almadinensis, A. amblyodonta, A. brasiliensis, A. communis, A. klotzschii, A. multicaulis, A. poiretti, A. villosa, and Acalypha wilkesiana. The species $A$. almadinensis, A. klotzschii, and A. villosa are endemic to Brazil.

The first palynotaxonomical studies of Euphorbiaceae to include Acalypha species were published by Punt (1962), who examined six species, and by Miller (1964), who studied 13 species occurring in the United States. Those studies did not indicate significant palynological variations within the genus, perhaps because both were undertaken using only light microscopy (LM). Subsequent pollen studies of the genus were made by Erdtman (1966), Fernandez-Gonzales \& Lobreau-Callen (1996), Lobreau-Callen \& Suarez-Cervera (1994), and Nowicke \& Takahashi (2002). The most recent and complete study, however, considering the size and diversity of the genus, was that of Sagun et al. (2006), which included 73 species. Those authors considered pollen data to be effective in aiding species and genus delimitations, with the pollen grains of the Acalypha species exhibiting significant variations in pollen size, the numbers of apertures, aperture distributions, and exine ornamentation.

There is still a very large gap in our knowledge concerning Acalypha in Brazil, and the genus will require more consistent diagnostic characters that could assist in better taxonomic delimitations of its taxa. We therefore sought to characterize the pollen morphology of species of the genus Acalypha, with emphasis on species occurring in Bahia State, Brazil, and investigate the palynological relationships between Acalypha and the related groups Mareya and Spathiostemon and to expand our knowledge about the group in Brazil.

\section{Materials and methods}

The present research focused on the pollen morphology of species occurring in Bahia State, Brazil, based on surveys of herbaria and consultations of the specialized literature (Pax \& Hoffman 1924; Sousa et al. 2019; Flora do Brasil 2020 2018), including Acalypha almadinensis, A. amblyodonta, A. brasiliensis, A. communis, A. klotzschii, A. multicaulis, A. poiretti, and A. villosa. Among those species, only A. villosa belongs to the subgenus Linostachys, the others are in Acalypha subg. Acalypha (Pax \& Hoffman 1924).

For the pollen analysis, flower buds were collected from exsiccates deposited in the CEPEC and HUEFS herbaria (acronyms according to Thiers 2020), the specimens investigated are cited in the supplementary material (List S1 in supplementary material).
The processing of pollen grains for light microscopy examination followed the methodology proposed by Erdtman (1960), using the acetolysis technique, and mounting permanent slides for analyses. The diameters (polar and equatorial) of 25 randomly chosen pollen grains were measured. Measurements of exine thickness were performed on ten pollen grains. The prepared slides were deposited in the Laboratório de Micromorfologia Vegetal da Universidade Estadual de Feira de Santana of Bahia.

Observations were also made using scanning electron microscopy. The acetolyzed pollen grains used were dehydrated in an increasing ethyl alcohol series (50, 70, 90, and $100 \%$ ), metalized with gold, and electron micrographs are taken. Palynological descriptions were based on the nomenclature of Punt et al. (2007) and Halbritter et al. (2018).

Nowicke \& Takahashi (2002) and Sagun et al. (2006) were used to provide pollen data on Mareya and Spathiostemon to establish the taxonomic relationships of some pollen characters among related genera of Acalypha.

\section{Results and discussion}

\section{General morphology}

Acalypha pollen grains are small; the specimens analyzed here had mean equatorial diameters (in polar view) generally ranging between 12-14 $\mu \mathrm{m}$ (Tab. 1, Fig. 1-3). Acalypha poiretti (Noblick, LR 2987) had the smallest grains (12.1 $\mu \mathrm{m}$ diameter) (Fig. 1I) and A. villosa (Mass, PJM 6962) the largest $(21.5 \mu \mathrm{m})$. Our measurements were similar to the ranges and sizes described by Nowicke \& Takahashi (2002) for common species. According to Sagun et al. (2006), large pollen grains, such as those found in A. villosa (a species of the subgenus Linostachys, a phylogenetically basal clade (see cladogram in Sagun et al. 2006)), can be interpreted as ancestral, with the smaller grains of most taxa representing a derived condition (including $A$. poiretti, which had the smallest diameters among the specimens analyzed here, and is one of the last derived taxa according to the cladogram). This evolutionary trend toward smaller grains may reflect ongoing adaptations for wind dispersal (Culley et al. 2002; Friedman \& Barrett 2009), including branched stigmas and vermiculiform anthers.

The shapes of pollen grains observed here (suboblate and oblate spheroidal, Tab. 1) seem to be common among Acalypha species according to previously published studies of other Euphorbiaceae species/genera (e.g., Nowicke \& Takahashi 2002; Sagun et al. 2006; Silva et al. 2016; Souza 2017). Pollen amb among the Acalypha species were circular (in A. brasiliensis, A. communis, A. klotzschii, and A. multicaulis) or subcircular (in A. almadinensis, A. amblyodonta, A. poiretti, and A. villosa). According to the definition of 
Table 1. Morphometric characters and shape of the pollen grains of species of the Acalypha (Euphorbiaceae).

\begin{tabular}{|c|c|c|c|c|c|c|c|c|c|}
\hline \multirow{2}{*}{ Species/Specimens/Herbaria } & \multicolumn{2}{|c|}{$\mathrm{PD}(\mu \mathrm{m})$} & \multicolumn{2}{|c|}{ ED $(\mu \mathrm{m})$} & \multicolumn{2}{|c|}{ EDp $(\mu m)$} & \multirow{2}{*}{ P/E } & \multirow{2}{*}{ Shape } & \multirow{2}{*}{$\begin{array}{l}\text { Exine } \\
(\mu \mathrm{m})\end{array}$} \\
\hline & $\bar{x} \pm S \bar{x}$ & FV & $\bar{x} \pm S \bar{x}$ & FV & $\bar{x} \pm S \bar{x}$ & FV & & & \\
\hline \multicolumn{10}{|l|}{ Acalypha almadinensis } \\
\hline Lopes, M.M.M 364 (SP) & $14.5 \pm 1.0$ & $12.5-15.0$ & $15.1 \pm 0.8$ & $12.5-17.5$ & $15.4 \pm 1.1$ & $12.5-17.5$ & 0.96 & OS & 1 \\
\hline \multicolumn{10}{|l|}{ A. amblyodonta } \\
\hline Noblick, L.R. 4322 (HUEFS) & $12.6 \pm 1.1$ & $10.0-15.0$ & $13.1 \pm 1.0$ & $12.5-15.0$ & $13.8 \pm 1.6$ & $12.5-17.5$ & 0.96 & OS & 1 \\
\hline Melo, E. 7425 (HUEFS) & $16.6 \pm 1.5$ & $12.5-20.0$ & $16.8 \pm 1.3$ & $15.0-20.0$ & $16.2 \pm 1.9$ & $12.5-20.0$ & 0.98 & OS & 1 \\
\hline Novais, J.S. de 14 (HUEFS) & $12.3 \pm 1.0$ & $10.0-15.0$ & $12.8 \pm 0.8$ & $12.5-15.0$ & $13.0 \pm 1.2$ & $12.5-17.5$ & 0.96 & OS & 1 \\
\hline Cardoso, D. 645 (HUEFS) & $15.1 \pm 1.5$ & $12.5-17.5$ & $16.1 \pm 1.4$ & $15.0-20.0$ & $15.0 \pm 1.2$ & $12.5-17.5$ & 0.93 & OS & 1 \\
\hline \multicolumn{10}{|l|}{ A. brasiliensis } \\
\hline Queiroz, L.P. de 12103 (HUEFS) & $12.5 \pm 1.6$ & $10.0-15.0$ & $13.2 \pm 1.3$ & $10.0-15.0$ & $13.0 \pm 1.7$ & $10.0-17.5$ & 0.94 & OS & 1 \\
\hline Melo, E. 13289 (HUEFS) & $12.5 \pm 1.0$ & $10.0-15.0$ & $13.2 \pm 1.1$ & $12.5-15.0$ & $14.3 \pm 1.5$ & $12.5-17.5$ & 0.95 & OS & 1 \\
\hline \multicolumn{10}{|l|}{ A. communis } \\
\hline Cortes, A.L. 60 (HUEFS) & $11.5 \pm 1.4$ & $10.0-15.0$ & $13.2 \pm 1.1$ & $12.5-15.0$ & $13.5 \pm 1.2$ & $12.5-15.0$ & 0.87 & SO & 1 \\
\hline \multicolumn{10}{|l|}{ A. klotzschii } \\
\hline Santos, T.S. dos 1390 (CEPEC) & $15.0 \pm 1.7$ & $12.5-17.5$ & $16.3 \pm 1.4$ & $15.0-20.0$ & $16.0 \pm 2.1$ & $12.5-20.0$ & 0.92 & OS & 1 \\
\hline \multicolumn{10}{|l|}{ A. multicaulis } \\
\hline Carvalho, A.M. de 531 (CEPEC) & $12.1 \pm 0.8$ & $10.0-12.5$ & $13.0 \pm 1.0$ & $12.5-15.0$ & $13.5 \pm 1.2$ & $12.5-15.0$ & 0.93 & OS & 1 \\
\hline Melo, E. 6949 (HUEFS) & $16.0 \pm 1.2$ & $15.0-17.5$ & $17.6 \pm 1.1$ & $15.0-20.0$ & $16.9 \pm 1.4$ & $15.0-20.0$ & 0.91 & OS & 1 \\
\hline Hage, J.L. 724 (HUEFS) & $12.0 \pm 1.0$ & $10.0-12.5$ & $12.8 \pm 0.8$ & $12.5-15.0$ & $12.9 \pm 0.9$ & $12.5-15.0$ & 0.94 & OS & 1 \\
\hline Moraes, A.O. 07 (HUEFS) & $14.1 \pm 1.2$ & $12.5-15.0$ & $14.3 \pm 1.3$ & $12.5-17.5$ & $14.7 \pm 1.8$ & $12.5-17.5$ & 0.98 & OS & 1 \\
\hline Guedes, M.L. 16199 (HUEFS) & $15.7 \pm 1.5$ & $12.5-17.5$ & $17.0 \pm 1.7$ & $15.0-20.0$ & $17.0 \pm 1.7$ & $15.0-20.0$ & 0.92 & OS & 1 \\
\hline \multicolumn{10}{|l|}{ A. poiretti } \\
\hline Brito, H.S. 171 (CEPEC) & $11.7 \pm 1.3$ & $10.0-15.0$ & $12.5 \pm 1.2$ & $10.0-15.0$ & $12.3 \pm 1.6$ & $10.0-15.0$ & 0.93 & OS & 1 \\
\hline Noblick, L.R. 2987 (HUEFS) & $10.8 \pm 1.1$ & $10.0-12.5$ & $11.3 \pm 1.2$ & $10.0-12.5$ & $12.1 \pm 1.3$ & $10.0-15.0$ & 0.96 & OS & 1 \\
\hline Noblick, L.R. 1971 (HUEFS) & $12.5 \pm 1.2$ & $10.0-15.0$ & $13.4 \pm 1.2$ & $12.5-15.0$ & $13.0 \pm 1.6$ & $10.0-17.5$ & 0.93 & OS & 1 \\
\hline \multicolumn{10}{|l|}{ A. villosa } \\
\hline Mass, P.J.M. 6962 (CEPEC) & $19.8 \pm 1.4$ & $17.5-22.5$ & $21.9 \pm 1.4$ & $20.0-25.0$ & $21.5 \pm 1.6$ & $17.5-25.0$ & 0.90 & OS & 1 \\
\hline Sousa, A.A.C 28 (SP) & $16.2 \pm 1.2$ & $15.0-17.5$ & $17.1 \pm 0.9$ & $15.0-17.5$ & $17.3 \pm 1.7$ & $15.0-20.0$ & 0.94 & OS & 1 \\
\hline
\end{tabular}

PD: polar diameter, ED: equatorial diameter, Edp: equatorial diameter in polar view, P/E: polar diameter/equatorial diameter; Shape - SO: suboblate, OS: oblate spheroidal.

Nowicke \& Takahashi (2002), Acalypha pollen grains are angulaperturate, thus quite triangular in amb.

According to Banks \& Rico (1999), oblate pollen grains with decreasing ectoaperture lengths may represent adaptations for reducing water losses and increasing pollen viability. The smaller the apertures of pollen grains, the more reduced will be their water losses. That characteristic is also favorable to pollen dispersal.

\section{Apertures}

The pollen apertures of Acalypha taxa are colporate, with fastigium (Fig. 1). The ectoapertures are short (brevicolpate), and the endoapertures are generally circular and restricted to the ectoaperture area. A 3-colporate pattern was most frequent in all of the species examined, although 4-colporate pollen grains (and more rarely 5 - in A. multicaulis and 6-colporate in A. villosa) were observed (Tab. 2). That heteromorphism in terms of the numbers of apertures was observed in all species, and was likewise reported by Sagun et al. (2006). Acalypha amblyodonta, A. brasiliensis, A. communis, A. klotzschii, and A. poiretti produced some 4-aperturate pollen grains, although 3-aperturate pollen predominated in those species (> 75\%). Sagun et al. (2006) described A. brasiliensis as 3-4-5-aperturate, and A. poiretti as 3-4-aperurate. We found no 5-aperturate pollen in A. brasiliensis, however. Acalypha multicaulis produced up to $61 \%$-aperturate pollen, and occasionally up to $7 \%$ 5 -aperturate pollen. A. villosa produced approximately $40 \%$ 4 -aperturate pollen but very rarely 6 -aperturate $(<1 \%)$. Concerning Acalypha villosa, our results differed from those of Sagun et al. (2006), who reported only 5-aperturate pollen among their specimens. Nowicke \& Takahashi (2002) reported that 3 -aperturate pollen was the most representative and frequent type among members of Acalyphoideae, although pollen with more than 3 apertures were sporadically found.

Small ectoapertures can lead to misidentifications of the apertural type by inexperienced observers, mainly when using light microscopy. Wurdack et al. (2005), for example, defined Acalypha pollen as "porate". Another factor that can hinder the identification of short ectoapertures is the presence of occlusive elements/extensions at the margines of the apertures (Sagun et al. 2006).

Apertural number heteromorphism in pollen grains can be caused by different factors. Stanley \& Linskens (1974) noted that one environmental factor that can cause variations in the numbers of pollen apertures is temperature. Dajoz et al. (1993), in their study of the Viola, argued that 

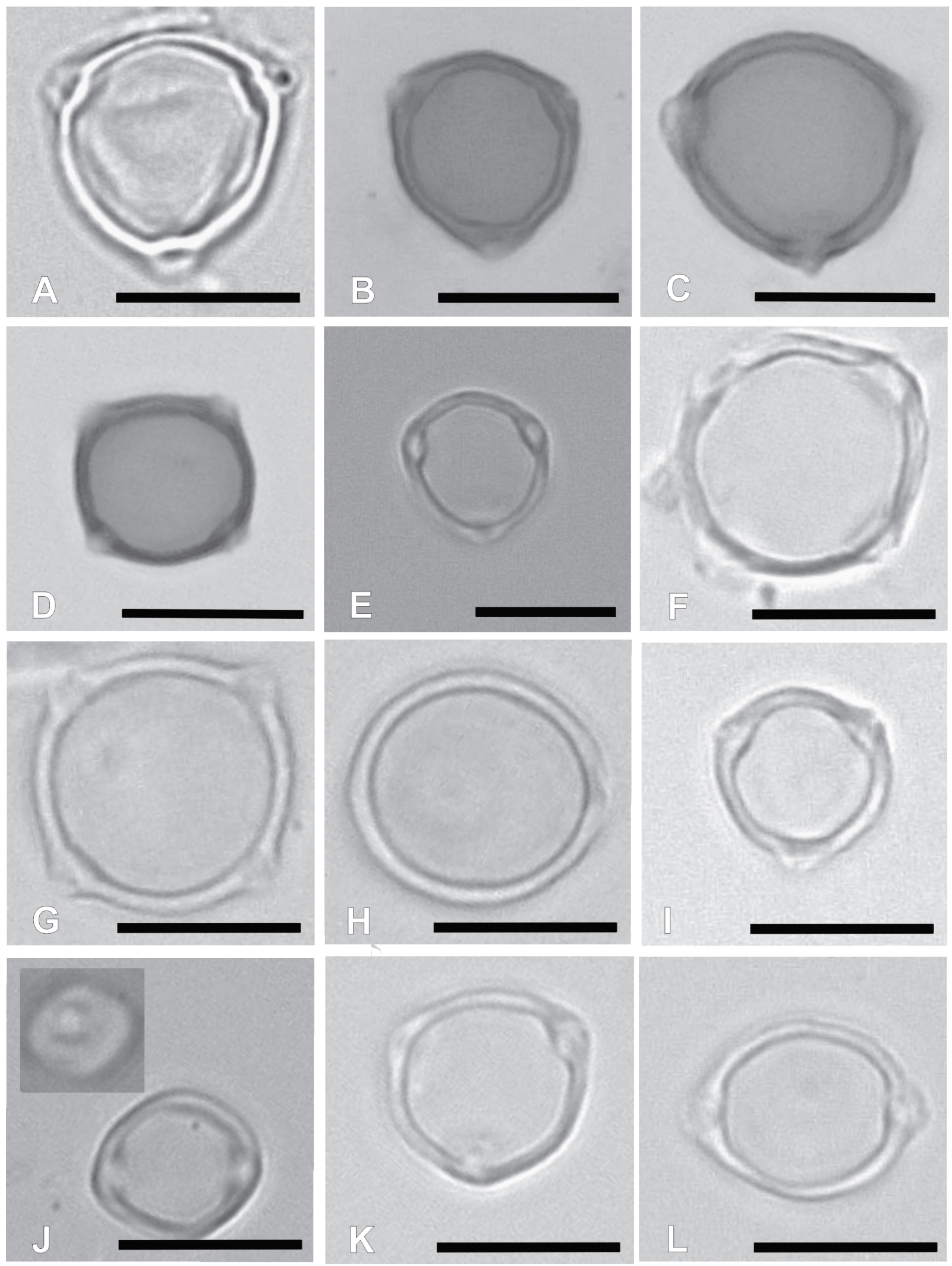

Figure 1. Photomicrographs of the pollen grains of Acalypha species from Bahia State, Brazil. Acalypha almadinensis: A) polar view. Acalypha amblyodonta: B) polar view. Acalypha brasiliensis C-D) polar view. Acalypha communis: E) polar view. Acalypha klotzschii: F) polar view. Acalypha multicaulis: G) polar view; H) equatorial view (high magnification). Acalypha poiretti: I) polar view; J) equatorial view, high magnification (detail: aperture at low magnification). Acalypha villosa: K) polar view; L) equatorial view, high magnification. Scale bars $=10 \mu \mathrm{m}$. 
polymorphism in terms of the numbers of apertures may be associated with increased reproductive fitness: the more apertures the grains have, the faster they will germinate - although pollen grains with more than 3 apertures have shorter viabilities.

Interestingly, if individuals produce pollen grains with different numbers of apertures, that mixed strategy could help guarantee more efficient pollination. Mignot et al. (1994) and Dajoz et al. (1995) considered variations in the ploidy levels of both sporophytes and gametophytes as the probable cause of pollen of aperture number heteromorphisms.

In terms of the presence of fastigium in the apertures of pollen grains, Nowicke \& Takahashi (2002) noted that the well-delimited fastigium in Acalypha are formed by the protrusion of the entire sexine into the aperture region and represents another characteristic that differentiates Acalypha from other genera of the subfamily Acalyphoideae.
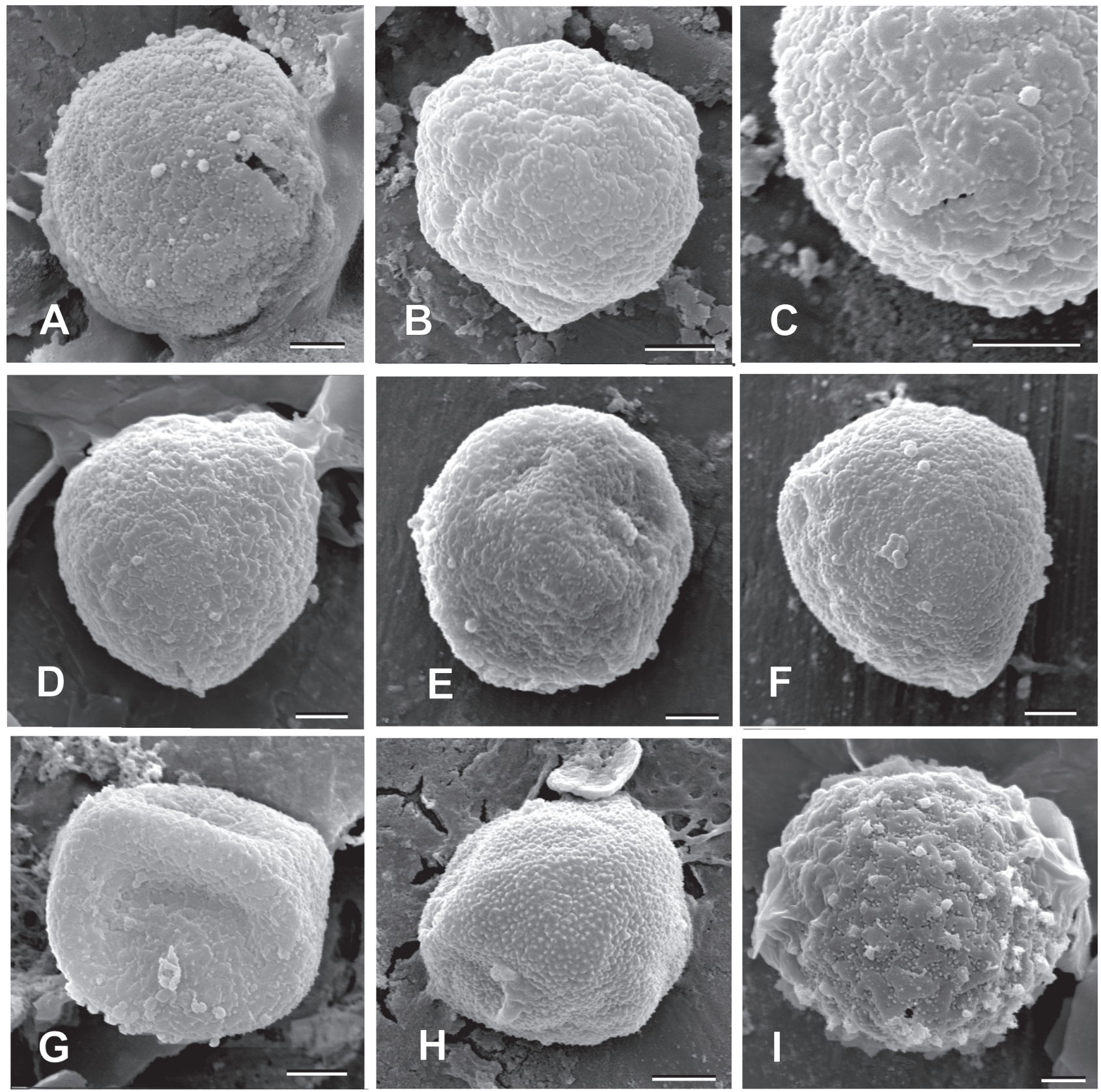

Figure 2. Electron micrographs of the pollen grains of Acalypha species from Bahia State, Brazil. Acalypha almadinensis: A) surface and aperture. Acalypha amblyodonta: B) surface, polar view; C) aperture detail. Acalypha brasiliensis: D) surface, polar view. Acalypha klotzschii: E) surface. Acalypha multicaulis: F-G) surface, polar view. Acalypha poiretti: H) surface, polar view. Acalypha villosa: I) polar view. Scale bars $=2 \mu \mathrm{m}$. 
Table 2. Proportions of the numbers of apertures in species of Acalypha (Euphorbiaceae). (\%, $\mathrm{n}=300)$.

\begin{tabular}{|c|c|c|c|c|}
\hline \multirow[t]{2}{*}{ Species/Specimens/Herbaria } & \multicolumn{4}{|c|}{ Apertural numbers } \\
\hline & 3 & 4 & 5 & 6 \\
\hline \multicolumn{5}{|l|}{ Acalypha almadinensis } \\
\hline Lopes, M.M.M. 364 (SP) & 27.6 & 72.3 & & \\
\hline \multicolumn{5}{|l|}{ A. amblyodonta } \\
\hline Noblick, L.R. 4322 (HUEFS) & 96.3 & 3.7 & & \\
\hline Melo, E. 7425 (HUEFS) & 100 & & & \\
\hline Novais, J.S. de 14 (HUEFS) & 98.3 & 1.7 & & \\
\hline Cardoso, D. 645 (HUEFS) & 94.6 & 5.4 & & \\
\hline \multicolumn{5}{|l|}{ A. brasiliensis } \\
\hline Queiroz, L.P. de 12103 (HUEFS) & 77 & 23 & & \\
\hline Melo, E. 13289 (HUEFS) & 87 & 13 & & \\
\hline \multicolumn{5}{|l|}{ A. communis } \\
\hline Cortes, A.L. 60 (HUEFS) & 89.3 & 10.7 & & \\
\hline \multicolumn{5}{|l|}{ A. klotzschii } \\
\hline Santos, T.S. dos 1390 (CEPEC) & 94 & 6 & & \\
\hline \multicolumn{5}{|l|}{ A. multicaulis } \\
\hline Carvalho, A.M. de 531 (CEPEC) & 57.3 & 42.7 & & \\
\hline Melo, E. 6949 (HUEFS) & 98 & 1.3 & + & \\
\hline Hage, J.L. 724 (HUEFS) & 36.3 & 61.3 & 2.4 & \\
\hline Moraes, A.O. 07 (HUEFS) & 97 & 3 & & \\
\hline Guedes, M.L. 16199 (HUEFS) & 52.6 & 47.4 & & \\
\hline \multicolumn{5}{|l|}{ A. poiretti } \\
\hline Brito, H.S. 171 (CEPEC) & 98.3 & 1.7 & & \\
\hline Noblick, L.R. 2987 (HUEFS) & 99.3 & + & & \\
\hline Noblick, L.R. 1971 (HUEFS) & 98 & 2 & & \\
\hline \multicolumn{5}{|l|}{ A. villosa } \\
\hline Mass, P.J.M. 6962 (CEPEC) & 59.3 & 40.3 & & + \\
\hline
\end{tabular}

$(+)=$ rarely, less than $1 \%$.

\section{Exine}

The exine of Acalypha pollen grains is thin, ca. 1 thick. It was not possible to distinctly observe either the sexine or nexine using light microscopy. At that level of analysis, the ornamentation of the exine is very thin, and a shallow microreticulum and some granules (scabres) can sometimes be observed, although the pollen grains of most species are psilate.

The exine appears more ornate under scanning electron microscopy, with three patterns of ornamentation: microrugulate-scabrate (slightly rugulate-scabrate) in most species (Fig. 2A-G), areolate-rugulate in A. villosa (Figs. 2I, $3 \mathrm{~B}$ ), and microechinate in $A$. poiretti (Figs. $2 \mathrm{H}, 3 \mathrm{C}$ ). There were small supratectal elements (scabres) on the surface of the pollen grains of all species, positioned in the lowest areas of the ornamentation, on the edges of the rugulae. In Acalypha poiretti, those elements were more pointed, usually becoming microspines (Fig. 3C, arrow). Pollen grains having microrugulate-scabrate ornamentation patterns show variations in rugulae orientation, which are short with slightly protruding surfaces. The rugulae in A. villosa (Fig. 3B), initiate radially from the areolae, and have a wide and protruding central portion.

Ubisch bodies were observed as small spheres on all of the species (Figs. 2A, C-G, I, 3A-B). They were mentioned for A. brasiliensis by Silva et al. (2016), and appear to be common in other genera of Euphorbiaceae, such as Euphorbia (El-Ghazaly 1989, El-Ghazaly \& Chaudhary 1993). Those
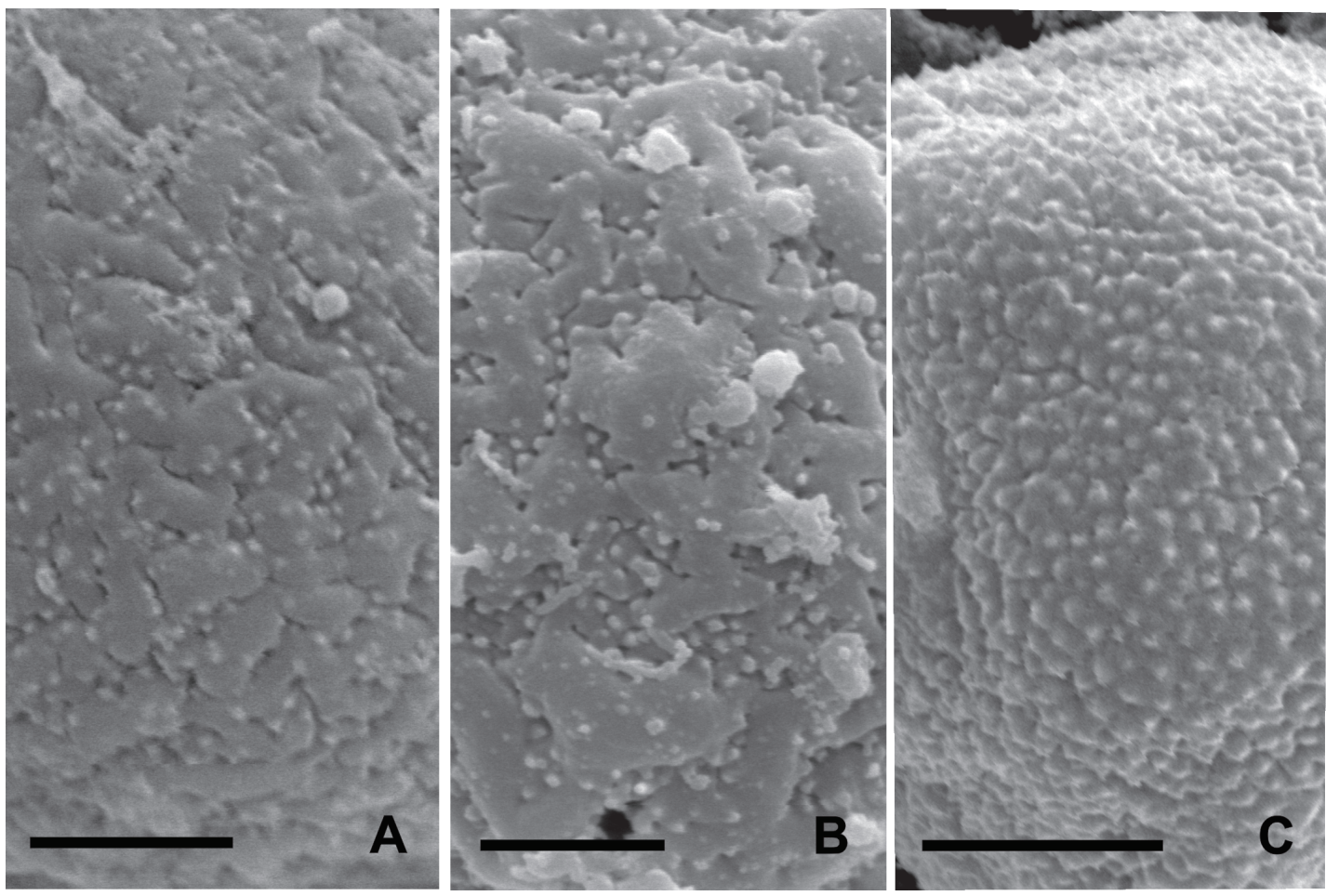

Figure 3. Electron micrographs of the exine ornamentation types identified in Acalypha species from Bahia State, Brazil. Acalypha amblyodonta: A) Acalypha villosa: B) Acalypha poiretti: C) Scale bars $=2 \mu \mathrm{m}$. 
structures have a composition similar to the exine, and can be used for taxonomic purposes in species circumscriptions (El-Ghazaly \& Chaudhary 1993). It was not possible to differentiate among Acalypha species by their Ubisch bodies, however, as they were all very similar.

The pollen ornamentation patterns described here were also observed by Sagun et al. (2006) in their analysis of 73 species of the genus. Nowicke \& Takahashi (2002) observed the same ornamentation patterns, but used a different terminology - sculptures with small irregularly shaped psilate areas separated by punctate-microspinulose areas.

\section{Palynological relationships between Acalypha and its related groups (Mareya and Spathiostemon)}

According to the molecular phylogeny of the uniovulate Euphorbiaceae, as elaborated by Wurdack et al. (2005), Mareya is the sister group of Acalypha and the genus Spathiostemon is a closely related group (and was used here as the out-group). Mareya species, according to Nowicke \& Takahashi (2002), produces small pollen grains (14.3$16.9 \mu \mathrm{m}$ ), prolate spheroidal, with 3-colpate or 3-colporate apertures, with long and narrow ectoapertures, prominent/ thick margins, and poorly-defined endoapertures; the exine is thin $(c .1 .0 \mu \mathrm{m})$, with a perforated and microequinate tectum. Thus, Mareya pollen grains differ from those of Acalypha by their prolate spheroidal shape, long ectoapertures, and poorly-defined endoapertures (Sagun et al. 2006). The exine ornamentation of Mareya is similar to that of Acalypha poiretti, which, as previously mentioned, is considered the most derived taxon among the other representatives of Acalypha studied here when taking pollen size into account.

Thus, the evolutive tendency of exine ornamentation is not considered here as a hypothesis. It is, however, valid to indicate scabrate ornamentation as an evolutive tendency in more derived taxa. That view becomes more evident when analyzing data published by Nowicke \& Takahashi for groups near Acalypha, such as Spathiostemon, which has small pollen grains (16.9-24.7 $\mu \mathrm{m})$, prolate spheroidal, colporate, with ectoapertures poorly developed and without margins, operculum absent, lalongate and poorly developed endoapertures, tectum complete, ornamentation consisting of shallowly segmented supratectal striae, and exine ca. $0.9 \mu \mathrm{m}$ thick. The exine ornamentations in those pollen grains show higher degrees of specialization, and do not demonstrate scabrate or psilate structures (as observed in Acalypha taxa). As such, the scabrate ornamentation may be a more evolutionarily derived condition.

\section{Conclusion}

Even though morphological variations at the interspecific level are not common within the genus, Acalypha species demonstrated wide variability in terms of the pollen grain morphologies of the taxa studied here. When analyzed only by light microscopy, the pollen grains demonstrated a certain homogeneity of characters, suggesting it as a stenopalynous group, but further analysis, using scanning electron microscopy, established the existence of different pollen types for the genus, rectifying the previous view. The pollen grains studied may differ mainly in terms of the numbers of apertures (varying from three to six apertures per grain) and their exine patterns (which could be microrugulatescabrate [slightly rugulate-scabrate], areolate-rugulate, or microechinate). Thus, the genus can be considered euripalynous, as are most Euphorbiaceae taxa. Pollen size, aperture numbers, and the types of exine ornamentation in Acalypha favor the anemophilous dispersal syndrome of the genus, which is uncommon among other representatives of the family. This study corroborates the characteristics described for Acalypha in other studies and expands our palynological knowledge of species within the group.

\section{Acknowledgements}

The authors thank the Fundação de Amparo à Pesquisa do Estado da Bahia for the financial supporting; the Conselho Nacional de Desenvolvimento Científico e Tecnológico (CNPq \#304255/2019-0) for supporting FARS; the curators and staff of the herbaria cited; the Laboratório de Micromorfologia Vegetal da Universidade Estadual de Feira de Santana for the use of their light microscopy laboratory facilities; and the Instituto Oswaldo Cruz Research Center Gonçalo Moniz for access to their scanning electron microscope.

\section{References}

Banks H, Rico L. 1999. Pollen morphology and phylogenetic analysis of Eperua Aublet (Detarieae: Caesalpinioideae: Leguminosae). Grana 38: 261-276.

Cardiel JM, Muñoz-Rodríguez P. 2015. Synopsis of Acalypha (Euphorbiaceae) of Argentina, Paraguay and Uruguay. Annals of the Missouri Botanical Garden 101: 384-405.

Cardiel, J.M., Dorda E, Pardo de Santayana M. 2018. Acalypha Taxonomic Information System. http://www.acalypha.es/. 05 Dec. 2020.

Culley MT, Weller SG, Sakai A.K. 2002. The evolution of wind pollination in angiosperms. Trends in Ecology \& Evolution 17: 361-369.

Dajoz I, Till-Bottraud I, Gouyon PH. 1993. Pollen aperture polymorphism and gametophyte performance in Viola diversifolia. Evolution 47: 1080-1093.

Dajoz I, Mignot A, Hoss C, Tile-Bottraud I. 1995. Pollen aperture heteromorphism is not due to unreduced gametophytes. American Journal Botany 82: 104-111

Erdtman G. 1960. The acetolysis method. A revised description. Svensk Botanisk Tidskrift 39: 561-564.

Erdtman G. 1966. Pollen Morphology and Plant Taxonomy. New York, Hafner Publishing Co.

Fernandez-Gonzales D, Lobreau-Callen D. 1996. Le pollen de la tribu des Acalypheae (Acalyphoideae, Euphorbiaceae). Grana 35: 266-284.

Flora do Brasil 2020. 2018. Jardim Botânico do Rio de Janeiro. http:// floradobrasil.jbrj.gov.br/. 17 May 2018.

Friedman J, Barrett SCH. 2009. Wind of change: new insights on the ecology and evolution of pollination and mating in wind-pollinated plants. Annals of Botany 103: 1515-1527. 
El-Ghazaly G. 1989. Pollen and Orbicule Morphology of some Euphorbia Species. Grana 28: 243-259.

El-Ghazaly G, Chaudhary R. 1993. Morphology and Taxonomic Application of Orbicules (Ubisch Bodies) in the Genus Euphorbia. Grana 32: 26-32.

Halbritter H, Ulrich S, Grímsson F, et al. 2018. Illustrated Pollen Terminology. 2nd. edn. Vienna, Springer International Publishing.

Heywood VH, Brummit RK, Culham A, Seberg O. 2007. Flowering Plant Families of the World. Buffalo, Firefly Books.

Lobreau-Callen D, Suarez-Cervera M. 1994. Pollen ultrastructure of Hymenocardia Wallich ex Lindley and comparison with other Euphorbiaceae. Review of Palaeobotany and Palynology 81: 257-278.

Mignot A, Hors C, Dajoz I, et al. 1994. Pollen aperture polymorphism in the Angiosperms: important, possible causes and consequences. Acta Botanic Gallica 141: 109-222.

Miller LAW. 1964. A Taxonomic Study of the Species of Acalypha in the United States. Thesis PhD, Purdue University, Indiana.

Nowicke JW, Takahashi M. 2002. Pollen morphology, exine structure and systematics of Acalyphoideae (Euphorbiaceae), Part 4. Review of Palaeobotany and Palynology 121: 231-336.

Pax F, Hoffmann K. 1924. Euphorbiaceae - additamentum VII. In: A. Engler \& Prantl. Das Pflanzenreich regni vegetabilis conspectus. Leipzig, Verlag von Wilhelm Engelmann. p. 1-231.

Punt W. 1962. Pollen morphology of the Euphorbiaceae with special reference to taxonomy. Wentia 7:1-116.

Punt W, Hoen PP, Blackmore S, Nilsson S, Le Thomas A. 2007. Glossary of pollen and spore terminology. Review of Palaeobotany and Palynology 143: 1-81.
Sagun VG, Levin GA, Ham RWJM. 2006. Pollen morphology and ultraestructure of Acalypha (Euphorbiaceae). Review of Palaeobotany and Palynology 140: 123-143.

Silva FHM, Santos FAR, Lima LCL. 2016. Flora polínica das Caatingas: Estação Biológica de Canudos (Canudos, Bahia, Brasil). Feira de Santana, Micron Bahia.

Souza LR, Saba MD, Santos FAR. 2017. Pollen morphology of the Acalyphoideae and Euphorbioideae (Euphorbiaceae) of the Caatinga ecoregion in Brazil. Plant Systematics and Evolution 303: 1161-1180.

Seberg O. 1984. Taxonomy and phylogeny of the genus Acalypha (Euphorbiaceae) in the Galapagos Archipelago. Nordic Journal of Botany 4: 159-190.

Sousa AAC, Codeiro I, Caruzo MBR. 2019. A New Species of Acalypha L. (Euphorbiaceae) from the Brazilian Atlantic Rain Forest. Systematic Botany 44: 346-348.

Stanley RG, Linskens HF. 1974. Pollen: Biology, Biochemistry and Management. New York, Springer.

Thiers B. 2020, continuously updated. Index Herbariorum: a global directory of public herbaria and associated staff. New York Botanical Garden's virtual herbarium. http://sweetgum.nybg.org/science/ih/. 10 Sept. 2020.

Webster GL. 1994. Synopsis of the genera and suprageneric taxa of Euphorbiaceae. Annals of the Missouri Botanical Garden 81: 33-144.

Wurdack KJ, Hoffmann P, Chase MW. 2005. Molecular phylogenetic analysis of uniovulate Euphorbiaceae (Euphorbiaceae sensu stricto) using plastid rbcL and trnL- F DNA sequences. American Journal of Botany 92: 1397-1420. 